\title{
ANALISA FAKTOR-FAKTOR YANG MEMOTIVASI PEREMPUAN BERWIRAUSAHA MELALUI BISNIS ONLINE (Studi Kasus Pada Ibu Muda di Kecamatan Bangkalan)
}

\author{
S Anugrahini Irawati ${ }^{1}$, Bambang Sudarsono ${ }^{2}$ \\ 'Dosen Fakultas Ekonomi Universitas Trunojoyo Madura, anugrahini.1962@gmail.com \\ ${ }^{2}$ Dosen Fakultas Ekonomi Universitas Trunojoyo Madura, sudarsono.bambang9@gmail.com
}

\begin{abstract}
The role of women in the business world needs to be considered, especially in the field of entrepreneurship. Technological developments in this case Information Technology can help simplify in conducting business activities known as online business. Online business activities help create new fields and job opportunities and help the family economy in particular. Most women who use the Internet as an opportunity to open jobs and fill their spare time in this case young mothers.

The purpose of this research is to know the factors that motivate women entrepreneurship through online business. The population in this study are young mothers of Bangkalan subdistrict who have an online business. This research is a quantitative research. Sample collection was done by distributing questionnaires, using nonprobability sampling method with purposive sampling technique to 75 young mothers who do business online. To find out what factors motivate women entrepreneurship through online business then researchers use descriptive qualitative research methods. The results showed that there are six factors that are formed in motivating women entrepreneurship through online business especially in young mothers are family factor, Self Interest, Employment Opportunities, Technical Knowledge, Entrepreneurial Experience, Family Background, Market Potencial.
\end{abstract}

Keywords: Factor Analysis, Motivation, Entrepreneurial Woman, Online Business

\begin{abstract}
ABSTRAK
Peran perempuan dalam dunia bisnis itu perlu dipertimbangkan, khususnya di bidang kewirausahaan. Perkembangan teknologi dalam kasus teknologi informasi dapat membantu menyederhanakan melakukan kegiatan usaha yang dikenal sebagai bisnis online. Kegiatan usaha online membantu menciptakan lapangan kerja baru dan kesempatan kerja serta membantu ekonomi keluarga. Hampir semua perempuan dalam hal ini ibu-ibu muda yang menggunakan internet memiliki kesempatan untuk membuka lapangan kerja dan mengisi waktu luang mereka.

Tujuan penelitian ini adalah untuk mengetahui faktor faktor yang memotivasi wirausaha perempuan melalui bisnis online. Populasi pada penelitian ini adalah ibu-ibu muda dari kecamatan bangkalan menjalani bisnis online. Penelitian ini adalah penelitian kuantitatif. Pengumpulan data dilakukan dengan mengedarkan kuesioner, menggunakan nonprobability sampling dengan teknik sampling purposive yaitu sebanyak $75 \mathrm{ibu}$ ibu muda yang melakukan bisnis online. Dalam upaya mencari tahu faktor faktor apa saja yang menjadi semangat dan motivasi bagi bisnis online melalui wirausahawan perempuan, maka peneliti menggunakan metode penelitian kualitatif deskriptif. Hasilnya menunjukkan bahwa ada enam faktor yang terbentuk dalam memotivasi wirausahaan perempuan melalui bisnis online terutama pada ibu-ibu muda yaitu faktor keluarga, kepentingan pribadi, kesempatan kerja, pengetahuan teknis, pengalaman wirausaha, latar belakang keluarga, dan pasar potensial.

Kata kunci: Analisis Faktor, Motivasi, Wirausaha Wanita, Bisnis Online
\end{abstract}




\section{PENDAHULUAN}

Banyaknya pengaggunguran tidak kentara menimbulkan masyarakat semakin bertambah kreatif dan inovatif dalam melakukan kegiatan berwirausaha/berbisnis, hal ini ditunjang dengan semakin canggihnya perkembangan teknologi khususnya teknologi informasi yang dapat dijadikan sebagai sarana untuk melakukan kegiatan tersebut. Kondisi semacam ini akan berdampak positif terhadap pertumbuhan industri sektor informal secara umum sehingga dapat membuka kesempatan kerja. Akhir-alhir ini pertumbuhan industri manufaktur sedang dan besar nasional melambat pada triwulan kedua tahun ini dibandingkan capaian pada periode yang sama tahun sebelumnya. Laju pertumbuhan industri melambat meski pada kuartal II/2017 industri menggenjot produksi untuk memenuhi permintaan puasa dan Lebaran.Data Badan Pusat Statistik (BPS) menunjukkan selama kuartal kedua 2017, industri besar dan sedang (IBS) hanya tumbuh 4\% (year-onyear/yoy). Pertumbuhan tersebut merupakan yang terkecil dibandingkan dengan kuartal II/2016 sebesar 5,06\% dan kuartal II/2015 sebesar 5,25\%. Selain IBS, BPS mencatat industri manufaktu mikro dan kecil (IMK) juga mengalami perlambatan. Sektor IMK hanya tumbuh 2,5\% pada kuartal II/2017 (yoy). Pada kuartal II/2016 dan kuartal II/2015, IMK tumbuh masing-masing 6,56\% dan 4,57\%.

Dalam rangka mengantisipasi pelambatnya pertumbuhan industri ini menurut Gati, pemerintah masih perlu menciptakan kebijakan-kebijakan yang berorientasi meningkatkan daya beli masyarakat sehingga kinerja industri skala besar, menengah, dan kecil akan kembali pulih.

Perkembangan kewirausahaan wanita di negara berkembang seperti Indonesia sangat berpotensi sebagai motor utama pendorong proses pemberdayaan wanita dan transformasi sosial (Tambunan, 2012). Sekilas jika dicermati, kiprah perempuan di dunia wirausaha sangat baik, berada di berbagai sektor usaha dan tidak jarang pula yang berhasil meraih sukses dan dikenal oleh publik. Saat ini, perempuan pengusaha banyak berkecimpung terutama pada usaha mikro dan kecil, namun demikian jumlahnya di Indonesia baru mencapai 0,1 persen dari total penduduk (Menkokesra, 2011). Hal ini tentu masih jauh dari harapan jika dibandingkan dengan total jumlah penduduk Indonesia. Perempuan pengusaha di Indonesia sebagian bergabung pada organisasi seperti Ikatan Wanita Pengusaha Indonesia (IWAPI) sebanyak 30.000 orang (Antaranews, 2013), sedangkan yang tergabung dalam Himpunan Pengusaha Muda Indonesia (HIPMI) baru mencapai kurang dari 10 persen dari sekitar 40.000 anggotanya (Warta Ekonomi, 2013). Di luar jumlah tersebut masih banyak perempuan pengusaha yang tidak berada dalam kelompok, komunitas maupun asosiasi tertentu. Melihat jumlah perempuan pengusaha tersebut nampaknya memang belum memadai, padahal jika dibandingkan dengan pengusaha pria. Sebenarnya jumlah perempuan pengusaha 14,3jt jumlah ini meningkat1,6jt dr jumlah sebelumx yang hanya berjumlah 12,7 jt orang naik dr 48,87 menjadi 55,04 mentri ketenagakerjaan Hanif Dhakiri beliau juga mengaku bahwa pihaknya akan mendorong dunia usaha dikalangan perempuan untuk terus berkembang. Ketua DPR RI Oesman Sapta Odang mengatakan bahwa perempuagn memiliki peran dan kontribusi yang sangat strategis dalam pembangunan bangsa. Menurutnya perempuan bisa menjadi kunci keberhasilan suatu bangsa dalam bidang pembangunan nasional. Oleh karena mari kita dorong agar perempuan indonesia dapat berkembang dalam pembanguanan.

Linda Amalia Sari Gumelar, mengatakan pada saat ini usaha mikro kecil dan menengah (UMKM) banyak didominasi oleh kaum wanita baik sebagai pemilik maupun pekerja, dimana Indonesia memiliki lebih dari 55,2 juta UKM dan mayoritas adalah industri rumahan dengan kontributor utamanya adalah wanita. Saat ini banyak wanita yang 
memainkan peran penting di dunia bisnis baik sebagai pimpinan di tempat dia bekerja atau menjadi pemilik di perusahaan yang dibangunnya sendiri. Berawal dari sekedar mengaktualisasikan diri, bekerja dan mandiri secara finansial ternyata sangat dinikmati oleh kaum wanita. Kebutuhan wanita untuk memperoleh informasi dan pengembangan diri semakin meningkat seiring dengan kemajuan teknologi telekomunikasi termasuk diantaranya melalui internet;

Berdasarkan data tersebut, peneliti ingin meneliti tentang faktor-faktor yang memotivasi perempuan berwirausaha melalui bisnis online. Selain itu, peneliti juga ingin mengetahui faktor yang paling dominan pada masing-masing faktor yang memotivasi perempuan berwirausaha melalui bisnis online. Adapun situs-situs yang biasa digunakan dalam bisnis online adalah: Lazada, blibli.com, OLX.com, shopee.com, traveloka.com, tokopedia.com, bukalapak.com, zalora.com, instragram dan facebook.

\section{TINJAUAN TEORITIS}

\section{WIRAUSAHA}

Istilah wirausaha sebenarnya melekat pada diri seseorang dan biasanya sudah merupakan kesatuan yang dikenal istilah berjiwa wirausaha. Seorang wirausahawan (entrepreneur) adalah seseorang yang bisa menciptakan bisnis baru dengan mengambil resiko dalam kondisi ketidakpastian untuk mencapai keuntungan pertumbuhan dengan cara mengidentifikasi peluang yang signifikan dan menggabungkan sumber-sumber daya yang diperlukan sehingga sumber daya itu bisa di kapitalisasikan secra maksimal. Seorang wirausahwan harus memiliki kemampuan yang kreatif dan inovatif dalam menemukan dan menciptakan berbagai ide. Setiap pikiran dan langkah wirausahawan adalah bisnis dan bisnis dalam mencapai keuntungan yang maksimal. Bahkan, mimpi seorang pebisnis sudah merupakan ide untuk berkreasi dalam menemukan dan menciptakan bisnis-bisnis baru.

Menurut Kamus Besar Bahasa Indonesia (KBBI), wirausaha (wiraswasta) adalah orang yang pandai atau berbakat mengenali produk baru, menentukan cara produksi baru, menyusun operasi untuk pengadaan produk baru, memasarkannya, serta mengatur permodalan operasinya.

2. PEREMPUAN WIRAUSAHA

Perempuan wirausaha dapat didefinisikan sebagai perempuan atau sekelompok perempuan yang memulai, mengatur dan mengoperasikan perusahaan bisnis. Banyak perempuan yang terjun kedalam bidang bisnis dengan berbagai macam alasan mengapa mereka tertarik menekuni bidang bisnis oneline ini. Beberapa faktor yang mendorong mengapa ibu-ibu muda termotivasi berbisnis online antara lain, ingin memperlihatkan kemampuan prestasinya, membantu ekonomi rumah tangga, frustasi terhadap pekerjaan sebelumnya dan sebagainya.

Dua kriteria perempuan wirausaha yaitu berdasarkan pada keterikatan pada cita-cita kewirausahaan dan peran gender secara konvensional. Empat tipe wirausaha diidentifikasi berdasarkan kriteria perempuan wirausaha, yaitu:

a. Semuanya berkompeten pada mimpi kewirausahaan dan berfikir konvensional tentang peran gender. Mereka cenderung terlibat dalam sebuah aktivitas yang biasa disebut sebagai "pekerja wanita" yang terpaksa untuk berbisnis karena kebutuhan ekonomi.

b. Wirausaha lokal menunjukan sedikit minat pada cita-cita kewirausahaan dengan berpegangan pada opini konvensional tentang peran gender. Mereka terlibat dalam 
aktivitas yang biasanya disebut dengan "pekerja wanita" yang bertujuan untuk mencari pengakuan diri dan ekspresi personal.

c. Inovator adalah perempuan profesional yang berpegang teguh pada cita - cita kewirausahaan dalam pencapaian diri melalui kesuksesan dalam berbisnis. perempuan ini tidak setuju dengan peran gender konvensional. Banyak dari wanita ini yang sebelumnya menerima rintangan dalam karirnya di organisasi besar dan bertekad untuk mengatasi rintangan melalui kepemilikan bisnis.

d. Wirausaha radikal tidak berpegang secara teguh dalam cita-cita kewirausahaan atau percaya pada peran gender konvensional. Perempuan secara umum menyatakan dirinya sebagai bagian dari pergerakan perempuan dan mereka berbisnis untuk meningkatkan derajat perempuan di masyarakat.

\section{MOTIVASI}

Secara umum motivasi adalah suatu usaha yang mengarah pada prilaku tertentu dalam mencapai suatu tujuan.

Motivasi berhubungan dengan :

a. Arah prilaku.

b. Kekuataan respons (usaha) setelah karyawan memilih mengikuti tindakan tertentu.

c. Ketahanan prilaku.

Motivasi adalah kesediaan untuk mengeluarkan tingkat upaya yang tinggi untuk tujuan organisasi yang dikondisikan oleh kemampuan upaya itu dalam memenuhi beberapa kebutuhan individual.

Motivasi merupakan salah satu faktor penentu dalam pencapaian tujuan. Motivasi berhubungan dengan dorongan atau kekuatan yang berada dalam diri manusia. Motivasi berada dalam diri manusia yang tidak terlihat dari luar. Sikap dan motivasi memiliki hubungan yang timbal balik dan akan menunjukkan kebutuhan dalam motivasi untuk memenuhi kebutuhan karakter yang harus dimiliki seorang wirausaha yaitu: pekerja keras (hard worker), tidak pernah menyerah (never surrender), memiliki semangat (spirit), memiliki komitmen (committed) yang tinggi.

Motivasi adalah kemauan untuk berbuat sesuatu, sedangkan motif adalah kebutuhan, keinginan, dorongan atau impuls. Motivasi seseorang tergantung kepada kekuatan motifnya. Motif dengan kekuatan yang sangat besar yang akan menentukan perilaku seseorang. Kekuatan motif ini dapat berubah karena terpuaskannya kebutuhan, bila kebutuhan telah terpuaskan maka motif akan berkurang, dan beralih kepada kebutuhan lain dan seterusnya. Serta, karena adanya hambatan, maka orang mencoba mengalihkan motifnya ke arah lain.

\section{ATRIBUT YANG MEMOTIVASI PEREMPUAN BERWIRAUSAHA}

Berdasarkan Penelitian Jesurajan dan Gnanadhas (2011) yang memotivasi wanita dalam berwirausaha adalah sebagai berikut:

a. Mandiri Secara Ekonomi (Economic Independence)

Seseorang dikatakan mandiri apabila dapat melakukan keinginan dengan baik tanpa adanya kebergantungan pada pihak lain dalam mengambil keputusan atau bertindak, termasuk mencukupi kebutuhan hidupnya

b. Tidak Puas Dengan Pekerjaan yang Ada (Dissatisfaction with the Existing Job) Seseorang tidak puas dengan pekerjaan yang sekarang, tidak ada peluang untuk maju, tidak ada kemungkinan naik pangkat, atau konflik di tempat kerja, ini semua dapat memicu seseorang memulai rintisan usaha sendiri

c. Pengangguran (Unemployment)

Menunjukkan bahwa orang-orang yang menganggur lebih memungkinkan untuk menemukan peluang berwirausaha dibandingkan dengan orang-orang yang bekerja. 
Jika orang yang menganggur dan tidak mendapatkan pekerjaan, mereka cenderung untuk memulai bisnis.

d. Mencari Tantangan (Seeking Challenge)

Wirausaha adalah orang yang menyukai usaha-usaha yang lebih menantang untuk mencapai kesuskesan atau kegagalan daripada usaha yang kurang menantang

e. Keinginan Pribadi (Self Interest)

Modal utama seorang wirausahawan adalah kemauan yang kuat serta rasa percaya diri. Mereka mempunyai keyakinan dan kepercayaan bahwa dengan tekad dan kemauan yang tinggi akan mampu mengatasi semua permasalahan dilapangan.

f. Kebanggaan Diri (Self Prestige)

Status sebagai pemilik perusahaan tentunya akan memberikan kebanggaan tersendiri yang tidak dirasakan jika dia bekerja dengan orang lain sebagai karyawan.

g. Tradisional/Turun Menurun (Traditional/Hereditary)

Sikap dan cara berpikir serta bertindak yang selalu berpegang teguh pada norma dan adat kebiasaan yang ada secara turun temurun, menurut tradisi (adat)

h. Kesempatan Kerja (Employment Opportunities)

Entrepreneur menciptakan pekerjaan dan bukan mencari pekerjaan, entrepreneur mampu menciptakan pekerjaan mulai dari untuk beberapa tenaga kerja saja sampai dengan ribuan pekerjaan

i. Bantuan Finansial (Financial Assistance)

Dalam memasuki arena bisnis atau memulai usaha baru, mencari sumber dana dan fasilitas, baik barang, uang maupun orang/pemodal. Sumber dana tersebut adalah berasal dari badan-badan keuangan seperti bank dalam bentuk kredit atau orang yang bersedia menjadi penyandang dana

j. Pengetahuan Teknis (Technical Knowledge)

Memiliki kompetensi dalam bidang rancang bangun sesuai dengan bentuk usaha yang akan dipilih

k. Dorongan Keluarga (Encouragment From Family Members)

Keluarga sangat berperan penting dalam menumbuhkan serta mempercepat seseorang untuk mengambil keputusan berkarier sebagai entrepreneur, karena orang tua berfungsi sebagai konsultan pribadi, coach, dan mentornya

1. Penggunaan Dana Tidak Terpakai (Use of Idle Funds)

Salah satu faktor yang memotivasi seseorang dalam berwirausaha merupakan faktor fasilitas. Dimana salah satunya terdapat ketersediaan dana menganggur (dana yang tidak terpakai) pada persediaan finansial (tabungan) wirausaha

m. Fasilitas Infrastruktur (Infrastructural Facilities)

Infrastruktur yang memadai mengacu adanya pasar, transportasi, fasilitas dan lainlain yang harus tersedia dalam mengembangkan kewirausahaan.

n. Pengalaman Kewirausahaan (Entrepreneurial Experience)

Pendidikan formal dan pengalaman bisnis kecil-kecilan yang dimiliki oleh seseorang dapat menjadi potensi utama untuk menjadi wirausaha yang berhasil

o. Potensi Pasar (Market Potentials)

Peluang pasar sekecil apa pun harus diidentifikasi dengan baik, sehingga dapat mengambil peluang pasar tersebut dengan baik

p. Keinginan Keluarga (Family Members Interest)

Seseorang memulai usaha karena keluarga mereka sudah memiliki usaha sebelumnya. Orang tua atau saudara tersebut menganjurkan keluarga lainnya untuk membuka usaha sendiri atau meneruskan usaha. 


\section{q. Status Sosial (Social Status)}

Alasan sosial seseorang berwirausaha adalah untuk memperoleh gengsi atau status, agar dapat dikenal dan dihormati, menjadi contoh bagi orang agar dapat ditiru orang lain, dan agar dapat bertemu orang banyak.

r. Latar Belakang keluarga (Family Background)

Jika ada anggota keluarga, terutama yang berada dalam garis langsung keturunan keluarga, seperti kakek, nenek, ayah atau ibu yang menjadi entrepreneur maka seseorang cenderung akan meniru pola pikir, cara kerja, dan sikap entrepreneur dari keluarganya

Kedelapan belas atrubut tersebuat akan menjadi ukuran faktor yang makah yang mempunyai peranan yang lebih besar dalam memotivasi perempuan beriwirausaha melalui bisnis.

\section{FAKTOR-FAKTOR PEREMPUAN WIRAUSAHA SUKSES}

Centre of Entrepreneurs menunjukkan setidaknya lima alasan mengapa pengusaha wanita lebih baik dari pria. Adapun faktor-faktor tersebut adalah sebagai berikut:

a. Wanita adalah pengambil risiko yang bijaksana

Baik pria maupun wanita dengan track record kewirausahaan mengatakan mereka siap untuk menerima danmengambil risiko sesuai dengan riset Centre of Entrepreneurs. Tetapi wanita memiliki 87 persen kemampuan melihat diri mereka sebagai pengambil risiko keuangan, dibandingkan dengan pria yang hanya 73 persen. Sementara 80 persen perempuan mengatakan mereka cenderung melihat peluang dimana orang lain melihat hal itu sebagai risiko, dibandingkan dengan lakilaki yang hanya 67 persen. Wanita begitu juga lebih cekatan melakukan pendekatan bisnis dengan penilaian yang realistis dari bahaya di masa mendatang.

b. Wanita tidak over confidence

Hanya 42 persen pengusaha wanita yang mengatakan dimana bisnis mereka saat ini sedang berada di puncak kesuksesan, sementara 62 persen pemimpin pria menggambarkan kinerja mereka baik. Ini bukan karena pengusaha wanita melakukan pekerjaan kurang baik daripada pria. Tapi pada kenyataannya, analisis bisnis yang dipimpin oleh pengusaha pria dan wanita masing-masing mengungkapkan bahwa pengusaha wanita benar-benar melakukan lebih kuat.

c. Wanita lebih ambisius

Lebih dari dua-pertiga dari wanita saat ini tertarik untuk memulai bisnis mereka sendiri dalam tiga tahun ke depan. Centre of Entrepreneurs mengungkapkan, pria lebih sedikit persentasenya, yakni kurang dari sepertiganya.

Dan, berdasarkan pengakuan kalangan pengusaha sudah menjalankan bisnis mereka sendiri, 47 persen wanita tertarik untuk memulai bisnis lain dalam tiga tahun ke depan dibandingkan dengan pria yang hanya 18 persen dalam melakukan usahanya.

d. Wanita punya perencanaan jangka Panjang

Jumlah pengusaha pria dan wanita yang mengatakan tertarik untuk mengembangkan bisnis selama lima tahun ke depan hampir sama, kirasan 82 persen dan 83 persen. Namun, pria dan wanita memiliki pandangan yang berbeda. Penelitian menunjukkanbahwa pada kenyataannya wanita lebih mungkin lebih bisa untuk menginvestasikan kembali keuntungan bebisnis untuk menghasilkan pertumbuhan yang stabil dan menguntungkan, sedangkan pria lebih mungkin untuk mencari pertumbuhan yang lebih cepat, yang harys didorong dengan investasi ekuitas, dan keluar lebih cepat. 
e. Wanita sukses menghadapi hambatan lebih baik dari pria

Pengusaha wanita harus bekerja lebih keras daripada pengusaha pria untukbisa berhasil dalam berbisnis. Satu dari lima wanita mengatakan, mereka tidak memiliki pengetahuan teknis yang diperlukan untuk bisnis. Seperempatpengusaha wanita mengatakan mereka tidak memiliki suatu jaringan yang diperlukan untuk membangun bisnis, sementara kurang dari satu dari 10 orang pengusaha yang mengatakan ini adalah masalah.

Akan tetapi masalah keberhasianl yang dicapai pengusaha wanita, menurut penelitian Centre of Entrepreneurs pengusaha wanita mampu membawa pulang dua kali lipat gaji pria.

f. Bisnis Online.

Kalau kita simak bahwa sebenarnya Bisnis Online terdiri dari 2 kata yakni Bisnis dan Online. Bisnis adalah suatu usaha atau aktivitas yang dilakukan oleh kelompok maupun individual, untuk mendapatkan laba/keuntungan dengan cara memproduksi produk maupun jasanya dalam rangka untuk memenuhi kebutuhan konsumennya. Sedangkan kata Online menurut kamus.web.id diartikan sebagai suatu kegiatan yang terhubung melalui jaringan komputer yang dapat diakses melalui jaringan komputer lainnya.

Sebagian orang mendefinisikan bisnis online adalah sesuatu aktifitas bisnis baik jasa maupun produk yang ditawarkan melalui media internet mulai dari negoisasi hingga kegiatan transaksinya, seperti menjual software, ebook dan sejenisnya tanpa harus bertatap muka dengan customer.

Sedangkan Darmawan 2013 mendifinisikan bisnis online adalah sebagai "sesuatu aktifitas bisnis yang sebagian atau seluruh kegiatannya dilakukan melalui media internet" apapun jenis bisnisnya dari mulai menjual hasil bumi hingga mobil. Dengan kata lain meski kita hanya seorang marketing dari sebuah perusahaan dan melakukan aktifitas marketing melalui media internet, bisa disebut sebagai pelaku bisnis online.

Bahkan yang luar biasa adalah, jika kita memiliki kemampuan memasarkan di internet, sangat terbuka kesempatan luas untuk dapat membantu memasarkan produk-produk orang lain baik perorangan maupun perusahaan-perusahaan dengan pendapatan yang menggiurkan.

Arti yang kita sering ketahui bahwa bisnis merupakan semua kegiatan yang dilakukan untuk mencari keuntungan baik dalam jumlah beras maupun kecil. Selanjutnya Bisnis diartikan sebagai suatu usaha atau aktivitas/kegiatan yang dilakukan oleh sekelompok maupun individual untuk mendapatkan laba dengan cara memrroduksi produk maupun jasanya untuk memenuhi kebutuhan konsumen. Jadi pengertian Bisnis Online adalah sebuah usaha untuk memutar uang demi mendapatkan keuntungan melalui internet. Maka syarat utama untuk Anda yang ingin berbisnis online adalah koneksi internet, dan modal adalah syarat nomor sekian. Artinya bahwa dengan bisnis online tidak membutuhkan modal yang besar kecuali perangkat internet sebagai pendukungnya.

Dalam www.pojokwesite.com mendifinisikan bisnis online adalah bisnis yang dijalankan secara online biasanya menggunajan jaringan internet sedangkan informasi yang akan disampaikan atau dijual biasanya menggunakan media website. Seiring dengan perkembangan teknologi informasi maka bisnis online memiliki prospek yang cukup besar pada saat ini maupun masa yang akan datang dimana hampir semua orang ingin melakukan kegiatan apapun dengan praktis dan mudah. Dalam memenuhi kebutuhan praktis adalah satu cara khas dari bisnis online 
dimana transaksi suatu bisnis dapat dilakukan dengan tanpa tatap muka atau bahkan tidak pernah kenal sebelumnya. Ada beberapa kelebihan yang ditawarkan dalam bisnid online selain praktis dan mudah yaitu tidak membutuhkan sumber daya manusia yang banyak, tempat bahkan bisa juga terhindar dari pajak.

\section{Pola Bisnis Online.}
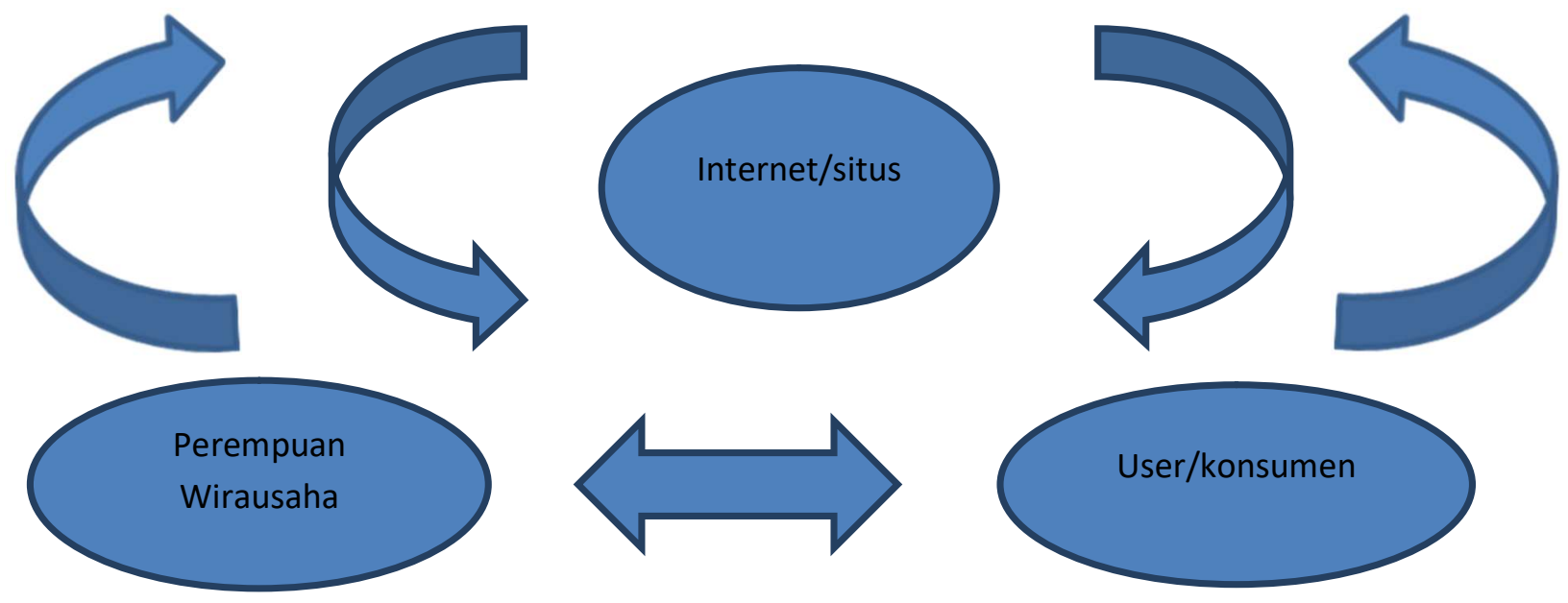

Keterangan:

Bahwa transaksi antara kedua belah pihak terjadi melalui perantara internet dengan situs yang dipilihnya sesuai keiinginan antara penjual dan pembeli. Selanjutnya pembeli dan penjual melakukan kesepakan pembayaran apakah melalui transfer atau bayar ditempat tentunya diperlukan kesepakatan terlebih dahulu.

\section{Kerangka Pemikiran}
1. Economic Independence
2. Dissatisfaction with the Existing Job
3. Unemployment
4. Seeking Challenge
5. Self Interest
6. Self Prestige
7. Traditional/Hereditary
8. Employment Opportunities
9. Financial Assistance
10. Technical Knowledge
11. Encouragment From Family Members
12. Use of Idle Funds
13. Infrastructural Facilities
14. Entrepreneurial Experience
15. Market Potentials
16. Family Members Interest
17. Social Status
18. Family Background)

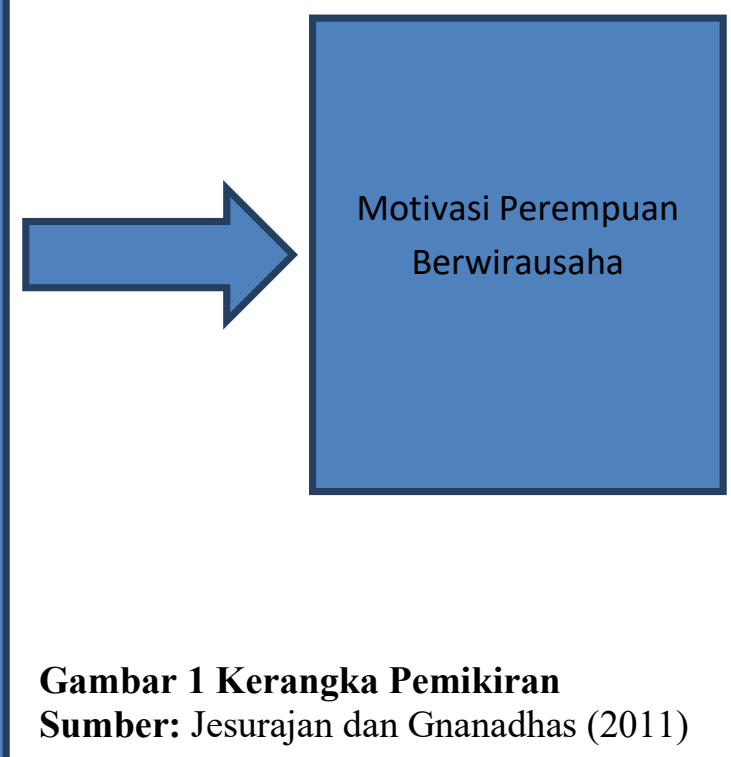

8 | Analisa Faktor-Faktor Yang Memotivasi Perempuan Berwirausaha... 
Berdasarkan kerangka pemikiran yang disajikan diatas, maka dapat ditetapkan suatu hipotesis sementara dalam penelitian ini adalah dari kedelapanbelas faktor tersebut diduga ada enam yang akan memotivasi perempuan berwirausaha melalui bisnis online.

\section{METODE PENELITIAN}

Penelitian ini merupakan penelitian grounded, menggunakan metode kualitatif dengan strategi deskrptif. Responden yang berpartisipasi dalam penelitian ini terdiri dari 75 orang perempuan pengusaha yang sudah berumah tangga yang berasal dari kalangan ibuibu muda. Seluruh responden berdomisili di Kecamatan Bangkalan. Keseluruhan data deskriptif yang diperoleh diproses dengan proses coding, dengan membuat pengelompokan respon berdasarkan pertanyaan terbuka yang diajukan kepada semua responden tentang faktor yang memotivasi keberhasilan usaha yang dilakukan mereka.

Disamping itu juga hasil jawawaban ditabulasi dan diprosentase jumlah jawaban dari masing-masing indikator sebagai dasar yang memotvasi perempuan berwirausaha. Setelah dilakukan perhitungan prosentase maka diambil prosentase diatas $70 \%$ sebagai ukuran kuatnya faktor yang memotivasi perempuan berwirausaha tersebut.

\section{Populasi dan Sample}

Populasi dalam penelitain ini adalah ibu-ibu muda se Kecamatan Kota Bangkalan yang menggeluti bisnis online. Mengingat jumlah populasi tidak diketahui secara pasti yaitu ibuibu muda yang menjalani bisnis online dari masing-masing desa seperti Pangeranan, Demmangan, Rong Tengnga, Kemayoran, Mor Kembang, Pesalagan, Mlajeh, Kidul Dalem, Saksak. Sedangkan jumlah sampel diambil sebanyak 75orang sebagai responden.

\section{HASIL PENELITIAN DAN PEMBAHASAN}

Berdasarkan hasil wawancara yang dilakukan langsung kepada responden maka diperoleh beberapa hasil, yakni data pribadi responden dan usahanya yang terdiri dari situs yang digunakan dalam berbisnis online, usia, pendidikan, atribut yang motivasi perempuan berwirausaha. Selain data tersebut, diperoleh data deskriptif berupa respon yang diberikan atas pertanyaan terbuka mengenai 18 faktor atribut yang motivasi perempuan berwirausaha khususnya para ibu-ibu muda di Kecamatan Bangkalan baik didaerah Demmangan, Pangeranan, kemayoran, Kraton, Saksak, Morkembang. Pajagan, Kidul Dalem.

\begin{tabular}{|c|c|c|c|}
\hline \multicolumn{2}{|c|}{ Karakteristik } & f & $\%$ \\
\hline \multicolumn{4}{|c|}{ Pendidikan } \\
\hline 1. & SMA & 11 & 14,67 \\
\hline 2. & Diploma (D3) & 9 & 12 \\
\hline 3. & Strata 1 & 52 & 69,33 \\
\hline 4. & Strata2 & 3 & 0,4 \\
\hline \multicolumn{4}{|c|}{ Pengguna Situs } \\
\hline & 1. Instagram & 20 & 26,67 \\
\hline & 2. Facebook & 10 & 13,33 \\
\hline & 3. Lazada & 17 & 22,67 \\
\hline & 4. Shopee.com & 12 & 16 \\
\hline & 5. Bukalapak.com & 8 & 10,67 \\
\hline & 6. OLX.com & 5 & 6,67 \\
\hline & 7. Tokopedia.com & 3 & 4 \\
\hline
\end{tabular}




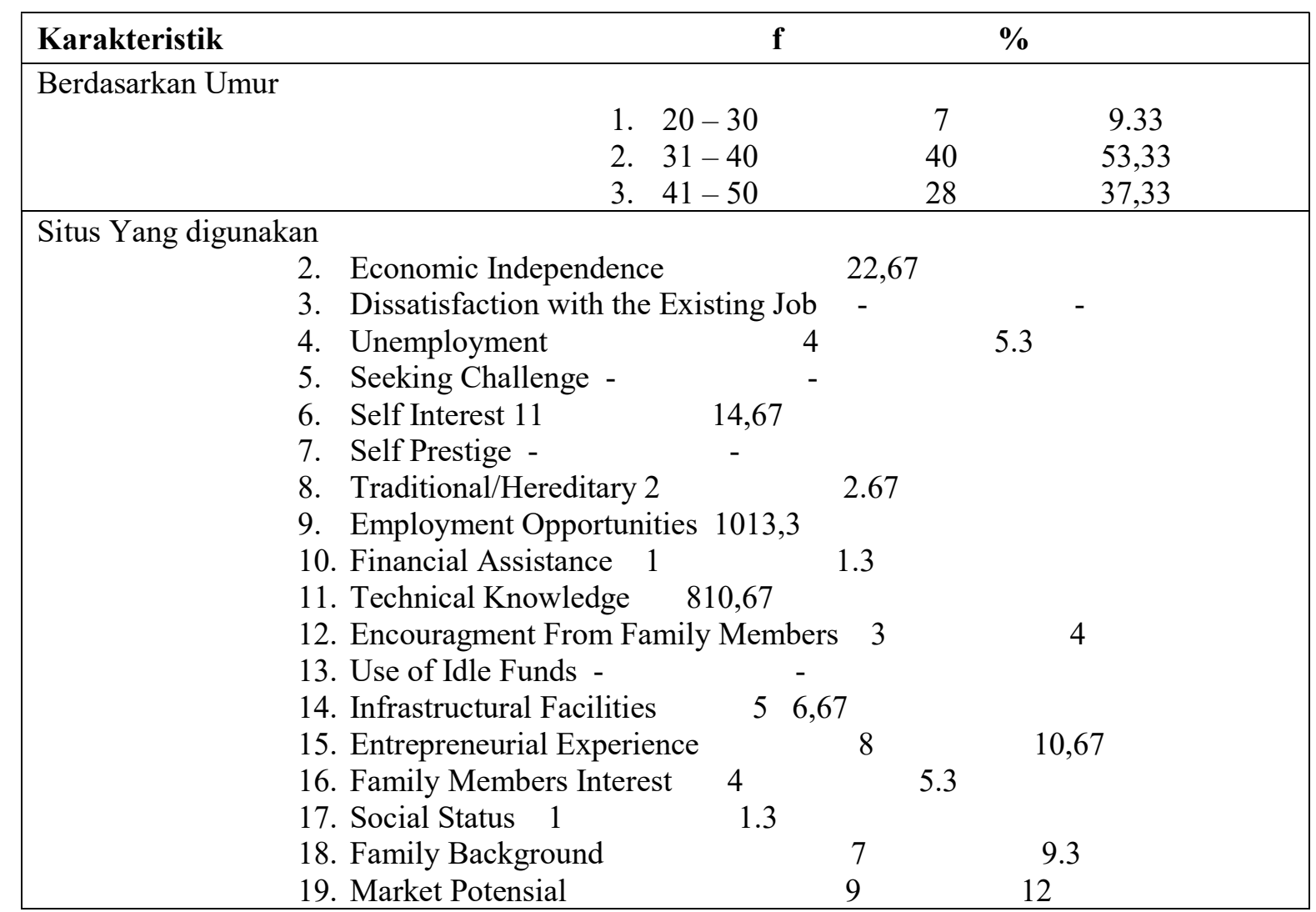

Sumber data yang diolah.

Dengan melihat data tersebut diatas menunjukkan bahwa Perempuan Wirausaha Berdasarkan Pendidikan pada tingkat sekolah menengah atas berjumlah 11 orang $(14,67 \%)$ menduduki peringkat ke dua, sedangkan yang berpendidikan diploma ada 9 orang $(12 \%)$ menduduki peringkat ke tiga. Selanjutnya yang paling banyak adalah pada tingkat strata 1 yaitu sebanyak 52 orang $(69,33 \%)$ dan pada tingkat pendidikan setrata 2 sebanyak 3 orang $(0,4 \%)$. Kondisi ini menunjukkan bahwa pada perempuan berwirausaha pada dasarnya dominan berada pada ibu-ibu muda dengan pendidikan strata 1 sesuai dengan style atau gaya mereka dalam kehidupan sehari-hari yang selalu update.

Selanjutnya perempuan berwirausaha berdasarkan situs yang digunakan, dengan melihat data dimana maka nampak bahwa jumlah perempuan wirausaha yang menggunakan situs instagram lebih banyak dibandingkan dengan pengguna situs lainnya yang mencapai 20 orang $(26,67 \%)$. Setelah dilakukan wawancara ternyata situs tersebut lebih mudah diakses dan digunakan secara pribadi para ibu muda pada umumnya. Pengguna situs peringkat ke2 adalah lazada.com yaitu ada 17 orang $(22,67 \%)$, dilanjutkan pada pengguna Shopee.com sebanyak 12 orang (16\%), peringkat selanjutnya adalah facebook sebanyak 10 orang $(13,33 \%)$. Pengguna situs selanjutnya adalah bukalapak.com sebanyak 8 orang $(10,67 \%)$, sedang pengguna situs Olx.com sebanyak 5 orang $(6,67 \%)$ sedangkam peringkat terakhir adalah pengguna situs Tokopedia.com sebanyak 3 orang (4\%).

Tabel diatas menunjukkan bahwa perempuan wirausaha berdasarkan umur dapat dikelaskan dengan interval 10 yaitu umur antara $20 \mathrm{~s} / \mathrm{d} 30$ sebanyak 7 orang $(9,33 \%)$, yang berusia antara $31 \mathrm{~s} / \mathrm{d} 40$ sebanyak 40 orang (53,33\%) lebih dari separuh ibu muda beraktivitas atau berbisnis online karena pada dasarnya mereka menggunakan hobby sebagai kegiatan yang positif yaitu menghasilkan keuntungan sebgai penghasilan. Selanjutnya yang berusia antara 41 s/d 50 sebanyak 28 orang $(37,33 \%)$. Hal ini menujukkan bahwa pada usia produktif merupakan saat yang potensial untuk melakukam 
aktivitas atau berbisnis online seuai dengan gaya hidup mereka yang selalu menggunakan komunikasi sosial dalam kehidupan sehari-hari mereka/

Berdasarkan hasil wawancara maka seperti yang terlihat dalam tabel diatas maka perempuan berwirausaha yang termotivasi karena alasan ingin Mandiri Secara Ekonomi (Economic Independence) sebanyak 2 orang (2,67\%) artinya bahwa hanya 2 orang dari 75 orang ibu muda yang beriwiraswasta dengan bisnis online yang menyatakan dia ingin mandiri secara ekonomi tanpa meninggalkan rumah.

Selanjutnya pada alasan atau motivasi berbisnis online karena tidak puas dengan pekerjaan yang ada (Dissatisfaction with the Existing Job) tidak ada yang menjawab, hal ini dikarenan mereka mempunyai alasan lain dimana pada dasarnya mereka berbisnis online karena mereka hanya mengisi waktu disela-sela kegiatan sebagai ibu rumah tangga dan juga sebagai karyawan dengan kata lain bisnis online yang dilakukan hanya sebagai pengisi waktu saja.

Alasan berbisnis online karena pengangguran (Unemployment) ada 4 orang atau 5,3\% motivasi karena menganggur bukan menjadi alasan berbisnis online bukan sematamata karena menganggur, akan tetapi karena merupakan hobby yang dijadikan peluang untuk iseng-iseng dan menghasilkan tambhan pendapatan. Jadi pengangguran bukan menjadi alasan mereka berbisnis online mengikuti trebd kegiatan ibu-ibu uda yang lain.

Mencari Tantangan (Seeking Challenge) bukan merupakan alasan mengapa perempuan berwirausaha secara online. Berbisnis online bukan suatu aktivitas dalam mencari tantangan akan tetapi tidak merupakan suatu pekerjaan yang menantang sehingga tidak ada yang memberi alasan terhadap pertanyaan tersebut.

Alasan perempuan termoivasi berbisnis online karena keinginan Pribadi (Self Interest) mencapai 11 orang atau 14,67\%, cukup tinggi dan signifikan, hal ini disebabkan karena adanya kemauan yang kuat serta rasa percaya diri yang tinggi. Mereka mempunyai keyakinan dan kepercayaan bahwa dengan tekad dan kemauan yang tinggi akan mampu mengatasi semua permasalahan dilapangan. Dengan demikian maka mereka memberikan alasan keingin pribadi mencapai 11 orang dari 75 responden dalam penelitian ini yaitu ibuibu muda.

Kebanggaan Diri (Self Prestige) bagi perempuan dalam berbisnis online tidak ada memberikan respon karena melakukan aktivitas atau berbisnis online bagi mereka bukanlah merupakan suatu kebanggaan, mereka beranggapan bahwa kegiatan ini dilakukan hanya ingin mengisi waktu dengan menghasilkan keuntungan walaupun hanya sebagai kegiatan sampingan bukan kegiatan pokok.

Motivasi atau alasan karena Tradisional/Turun Menurun (Traditional/Hereditary) perempuan berwirausaha hanya 2 orang dari 75 orang sebagai populasi atau 2,67\% karena sesuai dengan uraian sebelumnya bahwa perempuan harus tetap berpegang tegung pada adat atau tradisi kalu prilaku dan cara Sikap dan cara berpikir serta bertindak yang selalu berpegang teguh pada norma dan adat kebiasaan yang ada secara turun temurun, menurut tradisi (adat istiadat)

Adapun alasan berbisbis online karean Kesempatan Kerja (Employment Opportunities) ada 10 orang dari 75 responden atau mencapai $13,33 \%$ menjawab alasan tersebut karena pada dasarnya menyadari bahwa Entrepreneur menciptakan pekerjaan dan bukan mencari pekerjaan, sehingga entrepreneur mampu menciptakan lapangan pekerjaan mulai dari untuk beberapa tenaga kerja saja sampai menyerap ribuan tenaga kerja. Prinsip inilah yang dijadikan sebagai dasar mengapa responden yang memilih alasan tersebut untuk berbisnis online.

Bantuan Finansial (Financial Assistance) tidak menjadi alasan berarti bagi prempuan wirausaha yang ahanya ada 1 orang atau 1,3\% karena aktivitas bisnis online 
tidak membutuhkan bantuan modal besar dari pihak luar. Sesuai dengan dalam memasuki arena bisnis atau memulai usaha baru, mencari sumber dana dan fasilitas, baik barang, uang maupun orang/pemodal. Sumber dana tersebut adalah berasal dari badan-badan keuangan seperti bank dalam bentuk kredit atau orang yang bersedia menjadi penyandang dana.

Pengetahuan Teknis (Technical Knowledge) merupakan kompetensi yang dimiliki oleh ibu-ibu muda dalam berbisnis online pengetahuan mengenai internet, dari hasil wawancara yang dilakukan ternyata hanya ada 8 orang $(10,67 \%)$. Kondisi ini menunjukkan bahwa pengetahuan teknik menjadi alasan utama seseorang beraktivitas/berbisnis online karena pengetahuan tersebut sangat membutuhkan kepekataan terhadap perkembangan tenologi atau melek teknologi.

Alasan mendapat dorongan Keluarga (Encouragment From Family Members) dimana dalam berbisnis ini tidak membutuhkan dorongan keluarga dalam menumbuhkan serta mempercepat seseorang untuk mengambil keputusan berkarier sebagai seorang entrepreneur, karena orang tua dan keluarga dekat hanya berfungsi sebagai konsultan pribadi, coach, dan mentornya serta mempunyai pengaruh dalam mencapai kesuksesasan. Ternyata motif ini tidak mempunyai pengaruh penting dalam mendorong suksesnya dalam berbisnis online, karena terbukti yang menjawab alasan ini hanya ada 3 orang atau $4 \%$ dari 75 responden dalam penelitian ini, artinya fasiltas tenologi yang sangat dibutuhkan dalam kegiatan atau berbisnis online ini.

Berbisnis oneline dengan alasan penggunaan Dana Tidak Terpakai (Use of Idle Funds) juga ternyata bukan merupakan salah satu faktor yang memotivasi seseorang dalam berwirausaha karena dari 75 orang responden tidaka ada yang memilih faktor ini. Artinya bahwa berbisnis online ini tidak membutuhkan modal yang besar, karena dilakukan oleh ibu-ibu muda ini masih hanya merupakan pekerjaan sambilan dan bukan merupakan pekerjaan utama.

Faktor Fasilitas Infrastruktur (Infrastructural Facilitiesyang memadai mengacu adanya pasar, transportasi, fasilitas dan lain-lain yang harus tersedia dalam mengembangkan kewirausahaan ternyata menjadi fator yang penting dalam mendukungsuksesnya berbisnis online. Hal ini terbukti bahawa dari 75 responden ada 5 orang atau $6,67 \%$ yang mengatakan bahwa fasilitas infrastruktur menjadi kurabg penting dalam mendukung aktivitas, bisnis online bagi ibu-ibu muda tersebut.

Alasan Pengalaman Kewirausahaan (Entrepreneurial Experience) merupakan pendidikan formal dan pengalaman bisnis kecil-kecilan yang dimiliki oleh seseorang dapat menjadi potensi penting untuk beriwirausaha yang sukses, siapapun orangnya. Motivasi tersebut terbukti karena ada 8 orang atau $10,67 \%$ yang menjawab bahwa alasan pengalaman cukup berpengaruh dalam berbisnis online. Dengan berpengalam dalam berwirausaha maka mereka akan lebih tangguh dalam menjalani bisnis ini walaupun pernah jatuh bangun sekalipun.

Alasan Keinginan Keluarga (Family Members Interest) dimana pada dasarnya seseorang memulai usaha karena keluarga mereka sudah memiliki usaha sebelumnya. Orang tua atau saudara tersebut menganjurkan keluarga lainnya untuk membuka usaha sendiri atau meneruskan usaha. Secara kasat mata alasan ini menjadi penting dan berpengaruh dengan kuat karena didalamnya ada unsur ketrunan yang mewarnai aktivitas tersebut. Pada motivasi ini dari 75 orang responden ada 4 orang yang atau 5,33\% artinya masih cukup beralasan dalam mengapa mereka berbisnis online. Keadaan ini menggambarkan bahwa pengalaman yang menurun dari keluaraga dalam berbisnis sudah tidak menjadi alasan utama kemungkinan karean ibu-ibu muda hanya mengikuti trend saja. 
Adapun untuk alasan sosial seseorang berwirausaha adalah untuk memperoleh gengsi atau status Sosial (Social Status), agar dapat dikenal dan dihormati, menjadi contoh bagi orang agar dapat ditiru orang lain, dan agar dapat bertemu orang banyak. Motiv ini ternyata tidak berpengaruh karena yang menjawab hanya 1 orang atau $1,33 \%$ dari 75 orang responden ibu-ibu yang berbisnis online, jadi intinya bisnis ini tidak berpengaruh terhadap status sosial seorang wirausaha perempuan.

Latar Belakang keluarga (Family Background) merupakan atribut yang terakhir yang memoivasi pereempuan beriwirausaha melalui bisnis online cukup berpengaruh secara signifikan karena dari 75 orang responden ada 7 orang atau 9,33\%. Artinya jika ada anggota keluarga, terutama yang berada dalam garis langsung keturunan keluarga, seperti kakek, nenek, ayah atau ibu yang menjadi entrepreneur maka seseorang cenderung akan meniru pola pikir, cara kerja, dan sikap entrepreneur dari keluarganya atau dengan kata lain ada faktor keturunan kuat dalam memotivasi sesorang untuk berwirausaha.

Potensi Pasar (Market Potentials) seperti kita ketahui bersama bahwa peluang pasar sekecil apa pun harus diidentifikasi dengan baik, sehingga dapat mengambil peluang pasar tersebut dengan baik. Alasan inilah yang menyebabkan ada 9 orang atau $12 \%$ dari 75 orang responden yang meyakini bahwa potensi pasar menjadi faktor yang memotivasi ibu-ibu muda melakukan bisnis online karena tanpa pasar mereka tidak bisa menawarkan produknya.

\section{KESIMPULAN}

Menjadi ibu rumah tangga adalah pilihan yang tidak bisa di hindarkan bagi sebagian besar kaum wanita dewasa, sebagian ibu rumah tangga dapat bekerja di suatu perusahaan sebagai pegawai swasta ataupun pegawai negeri, dan mereka juga bisa sukses di karir yang di gelutinya, akan tetapi bagaimana jika anda sebagai ibu rumah tangga yang sehari harinya memang mengurus rumah tangga dan tidak bekerja tapi menginginkan penghasilan layaknya wanita karir dengan kemajuan teknologi maka banyak ibu-ibu muda yang menggunakan kondisi ini dengan berbisnis online dengan berbagai macam alasan. Berdasarkan hasil penelitian maka diambil suatu kesimpulan bahwa dari 18 atribut yang memotivasi perempuan berwirausahan melalui bisnis online. Dari hasil penelitian yang dilakukan ada 7 faktor yang memotivasi perempuan berwirausaha melalui binis online, dimana peneliti mengambil mininimal $9 \%$ yang dijadikan dasar bahwa atribut tersebut berpengaruh dominan yaitu: 1). Alasan unemployment ada 7 orang atau 9,3\%, 2). Self Interest ada 10 orang atau 13,3\%, 3). Employment Opportunities ada 9 orang atau 12\%. 4). Entrepreneurial Fasilities 8 orang atau 10,67\%, 5). Entrepreneurial Experience ada 7 orang atau 9,3\%,6). Family Background ada 7 orang atau 9,3\% dan yang terakhir adalahMarket Potentials ada 9 orang atau $12 \%$, hal ini menunjukkan bahwa dengan kemajuan teknologi dapat membantu seseorang untuk berbisnis secara effektif tanpa membutuhkan ruang gerak yang luas tapi mudah terjangkau.

\section{DAFTAR PUSTAKA}

Antaranews. (2013). Iwapi Targetkan 1 Juta Wanita Pengusaha.

http://www.antaranews.com/berita/372922/iwapi-targetkan-1-juta-wanita-pengusaha

Chattopadhyay, R., \& Ghosh, A. (2002). Predicting Entrepreneurial Success: A Sociopsychological Study. Journal of Entrepreneurship. 11; 21. DOI: $10.1177 / 097135570201100102$. 
Kader, R. A., Mohamad, R. M., and Ibrahim, C. A. (2009). Success Factos for Small Rural Entrepreneurs under the One-District-One -Industry Programme in Malaysia. Contemporary Management Research. 5.2.147-162.

Menteri Koordinator Kesejahteraan Rakyat. (2011). Pengusaha wanita masih minim.

Article. http://www.menkokesra.go.id/content/wanita-pengusaha-masih-minim

Panda.N.M, (2000). What brings entrepreneurial success in a developing region? Journal of Entrepreneurship. 9.199-212.

Parker, B.J. (2010). A Conceptual Framework for Developing the Female Entrepreneurship Literature. Journal of Research on Women and Gender. March. 1. 169 -190.

Reijonen, H., \& Kompulla, R. (2007). Perception of Success and Its Effect on Small Firm Performance. Journal of Small Business and Enterprise Development. 14. 4. 689-701. DOI $10.1108 / 14626000710832776$

Rmol. (2013). DPP Iwapi Motivasi Pengusaha Perempuan Untuk Jadi Pengusaha Tangguh

http://www.rmol.co/read/2013/10/22/130347/DPP-Iwapi-Motivasi-Pengusaha-Perempuan-UntukJadi-Pengusaha-Tangguh-

Sorokhaibam, R., \& Laishram, N. (2011). Women Entrepreneurship in Manipur,North-East India. Interdisciplinary Journal of Research in Business. 1.6.46-53.

Tambunan, T, (2009). Women Entrepreneurship in Asian Developing Countries: Their Development and Main Constraints. Journal of Development and Agricultural Economics. 1(2).27-40.

Tambunan, T. (2012). Usaha Mikro Kecil dan Menengah di Indonesia. Isu-isu Penting. Jakarta : Penerbit LP3ES.

Warta Ekonomi. (2013). Hipmi Berharap Porsi Jumlah Wanita Pengusaha Meningkat. Diakses dari http:// wartaekonomi.co.id/berita9636/hipmi-berharap-porsi-jumlah-wanita-pengusahameningkat.html. 